\title{
Estimation of Physicochemical Properties of 1-ethyl-3-methylimidazolium Thiocyanate Ionic Liquid Using Density and Surface Tension
}

\author{
Wanxiang Jin \\ Chemical Engineering School, Xuzhou College of Industrial Technology \\ PO box 221000, XuZhou, China \\ Tel: 86-516-857-8278 E-mail: xuch@mail.xzcit.cn \\ Jinsong Gui \\ College of Pharmacy, Guilin Medical College \\ PO box 541004, Guilin, China \\ Tel: 86-773-589-1689 E-mail: jinsonggui@163.com \\ Received: July 21, $2011 \quad$ Accepted: August 10, $2011 \quad$ Published: December 1, 2011 \\ URL: http://dx.doi.org/10.5539/ijc.v3n4p72
}

doi:10.5539/ijc.v3n4p72

Jiangshu Province's natural Science Research Program. NO. 09KJD150012 \& The research is financed by Education department of Guangxi Zhuang Autonomous Region. No. $2010101 \times 346$.

\begin{abstract}
The density and surface tension of the ionic liquid (IL) $\left[\mathrm{C}_{2} \mathrm{mim}\right][\mathrm{SCN}]$ (1-ethyl-3-methylimidazolium thiocyanate) were measured in a temperature range from (298.15 to 338.15) K. In terms of Glasser's semiempirical relation theory of ILs, the standard molar entropy and lattice energy of the homologous series of ILs [Cnmim][SCN] of the IL were estimated at $298 \mathrm{~K}$, respectively. Using Kabo's method and Rebelo's method, the molar enthalpy of vaporization of the IL, $\Delta_{l}^{g} H_{m}^{0}(298)$, at $298 \mathrm{~K}$ and, $\Delta_{l}^{g} H_{m}^{0}\left(\mathrm{~T}_{\mathrm{b}}\right)$, at hypothetical normal boiling point was estimated, respectively. According to the interstice model, the thermal expansion coefficient of the IL was calculated and in comparison with experimental value, it is in good agreement.In terms of semiempirical method, physicochemical properties molecular volume $\mathrm{Vm}$, parachor $\mathrm{P}$, surface tension $\gamma$, thermal expansion coefficients $\alpha$, of the homologue of $\left[\mathrm{C}_{n} \operatorname{mim}\right][\mathrm{SCN}](n=3,4)$ were predicted.
\end{abstract}

Keywords: $\left[\mathrm{C}_{2} \mathrm{mim}\right][\mathrm{SCN}]$, Physicochemical properties, Predicted

\section{Introduction}

L. Alonso $(2008,270,97-102)$ and U. Doman' ska $(2007,259,173-179)$ reported that Ionic liquids (ILs) are a novel class of chemical compounds which present the prospective of "designer solvents" since their physicochemical properties can be fine tuned by a judicious choice of the cation and anion. With their specific properties like negligible vapour pressure at room temperature and high solvating capacity for inorganic, organic and organometallic compounds, they can be designed to have a particular set of physico-chemical properties and thus can be designed for a particular application. Recently, there is a developing trend in literature toward estimation of physicochemical properties for ILs, which is to be commended because it provides valuable insight into the origins of the behavior of materials. In order to adapt to this trend better,this paper reports the following: (1) The density and surface tension of the $\mathrm{IL}\left[\mathrm{C}_{2} \mathrm{mim}\right][\mathrm{SCN}]$ were measured in the temperature range from (298.15 to 338.15) K. (2) Using Kabo's method and Rebelo's method, the molar enthalpy of vaporization of [C2mim][SCN] was estimated. (3) According to the interstice model, the thermal expansion coefficients of $\left[\mathrm{C}_{2} \mathrm{mim}\right][\mathrm{SCN}]$ were predicted. (4) In terms of Glasser's semiempirical relation of IL and a semiempirical method proposed in this work, physicochemical properties of homologous compounds of ILs were estimated. 


\section{Experimental}

The origins of the chemicals $\left[\mathrm{C}_{2} \mathrm{mim}\right][\mathrm{SCN}]$ (CAS, Merck, Germany $>98 \%$ ); The density of the sample was measured with an Anton Paar DMA 4500 oscillating U-tube densitometer. The temperature in the cell was regulated to $0.01 \mathrm{~K}$ with a solid state thermostat. The apparatus was calibrated daily with dry air and double distilled freshly degassed water and cleaned with absolute ethyl alcohol, followed by drying using air. Using the tensiometer of the forced bubble method, the surface tension of water was measured from (298.15 to 338.15) $0.05 \mathrm{~K}$ and was in good agreement with literature within the experimental error. After being dried in an oven, the surface tension of the IL was measured by the same method under dry argon in the same temperature range.

\section{Results and Discussion}

The measured density and of the 1-ethyl-3-methylimidazolium thiocyanate Ionic Liquids are listed in Table 1, respectively.

\subsection{Empirical density equation and estimating the volumetric properties of the homologous series of ILs}

The experimental values of $\ln \left(\rho / \mathrm{kg} \cdot \mathrm{m}^{-3}\right)$ against (T/K - 298.15) were fitted by the method of the least-squares, and an empirical equation, $\ln \left(\rho / \mathrm{kg} \cdot \mathrm{m}^{-3}\right)=0.11048-5.46 \cdot 10^{-4}(\mathrm{~T} / \mathrm{K}-298.15)$, was obtained. The correlation coefficient of the fitting is 0.99991 , with a standard deviation $\mathrm{s}=9.4 \cdot 10^{-5}$. According to the definition of the coefficient of thermal expansion, $\alpha$ is calculated as the following:

$$
\alpha=\frac{1}{V^{0}}\left(\frac{\partial V^{0}}{\partial T}\right) \rho=-\left(\frac{\partial \ln \rho}{\partial T}\right) \rho
$$

The slope of the empirical equation is the experimental value of $\alpha$ for the IL, that is, $\alpha$ (exp.) $=5.46 \cdot 10^{-4} \mathrm{~K}^{-1}$.

The molecular volume, $\mathrm{Vm}$, is the sum of cation and anion volume and may be calculated using eq 2 :

$$
V_{m}=M /\left(N \cdot \rho_{0}\right)
$$

where $\mathrm{M}$ is molar mass $\left(141.15 \mathrm{~g} \cdot \mathrm{mol}^{-1}\right)$ and $\mathrm{N}$ is Avogadro's constant. Using eq 2, Vm $=0.2099 \mathrm{~nm}^{3}$ for IL was obtained from the density value at $298.15 \mathrm{~K}$.

According Tong, J., Liu (2008, 112, 4381-4386) and Fang (2008, 112, 7499-7505), the contribution to the molecular volume per methylene (-CH2-) group is $0.0270 \mathrm{~nm}^{3}$ in ILs $\left[\mathrm{C}_{\mathrm{n}} \operatorname{mim}\right]\left[\mathrm{AlCl}_{4}\right](\mathrm{n}=1,2,3,4,5,6)$ and $0.0278 \mathrm{~nm}^{3}$ in ILs [Cnmim][Ala] (1-alkyl-3-methylimidazolium $\alpha$-aminopropionic acid salt) $(\mathrm{n}=2,3,4,5,6)$, which is in excellent agreement with a mean contribution of $0.0275 \mathrm{~nm}^{3}$ obtained by Glasser $(2004,421,87-93)$, from ILs $[\mathrm{Cnmim}]\left[\mathrm{BF}_{4}\right]$ and $[\mathrm{Cnmim}]\left[\mathrm{NTf}_{2}\right]$. This confirms that we may apply the mean value, $0.0275 \mathrm{~nm}^{3}$, to predict the volumetric properties of the homologues of $\left[\mathrm{C}_{n} \operatorname{mim}\right][\mathrm{SCN}](n=3,4,5,6)$ at $298.15 \mathrm{~K}$. The predicted values are given in Table 2 .

The values of $\gamma$ obtained at different temperature have been fitted against $\mathrm{T}$ by least-squares to a linear equation (see Figure 2). The correlation coefficient is 0.997 and the standard deviation is $0.07 \mathrm{~mJ} \cdot \mathrm{m}^{-2}$ for the fitting. From the slope of the fitted line, the surface excess entropy, Sa, could be obtained, that is, $\mathrm{Sa}=-(\partial \gamma / \partial T) p=76 \cdot 10-3$ $\mathrm{mJ} \cdot \mathrm{K}^{-1} \cdot \mathrm{m}^{-2}$. In addition, the surface excess energy likewise may be obtained from the surface tension measured in this work: $\mathrm{Ea}=\gamma^{-} \mathrm{T}(\partial \gamma / \partial T) \mathrm{p}=80.5 \mathrm{~mJ} \cdot \mathrm{m}^{-2}$. In comparison with fused salts reported by Adamson (1976, 3rd ed), for example, $\mathrm{Ea}=146 \mathrm{~mJ} \cdot \mathrm{m}^{-2}$ (for fused $\mathrm{NaNO}_{3}$ ), and the value of $\mathrm{E}_{\mathrm{a}}$ for $\left[\mathrm{C}_{2} \mathrm{mim}\right][\mathrm{SCN}]$ is much lower and is close to an organic liquid, for example, $67 \mathrm{~mJ} \cdot \mathrm{m}^{-2}$ (for benzene) and $51.1 \mathrm{~mJ} \cdot \mathrm{m}^{-2}$ (for octane). This fact shows that interaction energy between ions in $\left.\left[\mathrm{C}_{2} \mathrm{mim}\right][\mathrm{SCN}]\right]$ is less than that in fused salts.

According to Glasser's semiempirical relation (2004, 421, 87-93), the standard entropy for ILs, $\mathrm{S}_{0}$, can be calculated applying the following equation:

$$
\mathrm{S}_{0}\left(\mathrm{~J} \cdot \mathrm{K}^{-1} \mathrm{~mol}^{-1}\right)=1246.5 \times \mathrm{Vm}\left(\mathrm{nm}^{3}\right)+29.5
$$

Using eq 3 , the calculated values of $S_{0}$ for the homologous series $\left[\mathrm{C}_{n} \operatorname{mim}\right][\mathrm{SCN}](\mathrm{n}=2,3,4,5$, 6) were obtained and listed in Table 2.

The values of lattice energy for the homologous series $\left[\mathrm{C}_{\mathrm{n}} \operatorname{mim}\right][\mathrm{SCN}], \mathrm{U}_{\mathrm{POT}}$, may be estimated using eq 4 :

$$
\mathrm{U}_{\mathrm{POT}} / \mathrm{kJ} \cdot \mathrm{mol}^{-1}=1981.2[\rho / \mathrm{M}] 1 / 3+103.8
$$


where $\mathrm{M}$ is molar mass. The calculated results are listed in Table 2. From Table 2, it follows that the highest value, $\mathrm{U}_{\mathrm{POT}}=498.6 \mathrm{~kJ} \cdot \mathrm{mol}^{-1}$, of $\left[\mathrm{C}_{2} \mathrm{mim}\right][\mathrm{SCN}]$ is much smaller than the value of fused salts, for example, $\mathrm{U}_{\mathrm{POT}}$ $=613 \mathrm{~kJ} \cdot \mathrm{mol}^{-1}$ for the fused CsI, which possesses the lowest lattice energy among alkali halides. The low lattice energy is the underlying reason for forming an IL at room temperature.

\subsection{Predicting Vaporization Enthalpies for [ $\left.\mathrm{C}_{2} \mathrm{mim}\right][\mathrm{SCN}]$}

Kabo and colleagues $(2006,110,7303-7306)$ put forward an empirical equation for the estimation of the enthalpy of vaporization, $\Delta_{l}^{g} H_{m}^{0}(298 \mathrm{~K})$, of ILs:

$$
\Delta_{l}^{g} H_{m}^{0}(298 K)=A\left(\gamma \mathrm{N}^{2 / 3} \mathrm{~N}^{1 / 3}\right)+B
$$

where $\mathrm{V}$ is molar volume, $\mathrm{N}$ is Avogadro's constant, $\mathrm{A}$ and $\mathrm{B}$ are empirical parameters, and their values are $\mathrm{A}=$ 0.01121 and $\mathrm{B}=2.4 \mathrm{~kJ} \cdot \mathrm{mol}^{-1}$, respectively. The molar enthalpy value of vaporization for $\left[\mathrm{C}_{2} \mathrm{mim}\right][\mathrm{SCN}]$ was $140.2 \mathrm{~kJ} \cdot \mathrm{mol}^{-1}$ calculated from eq 5 .

In addition, Rebelo, et al. (2005, 109, 6040-6043) put forward a method of estimating the hypothetical temperature of normal boiling point (TNBP) of IL, $\mathrm{T}_{\mathrm{b}}$, in terms of critical temperature, $\mathrm{T}_{\mathrm{c}}$. They thought that the relationship between $\mathrm{T}_{\mathrm{b}}$ and Tc is $\mathrm{T}_{\mathrm{b}} \approx 0.6 \mathrm{~T}_{\mathrm{c}}$ for ILs. The molar enthalpy of vaporization for the ILs at TNBP, $\Delta_{l}^{g} H_{m}^{0}\left(\mathrm{~T}_{\mathrm{b}}\right)$, can be estimated by the Trouton constant $\left(\approx 90 \mathrm{~J} \cdot \mathrm{mol}^{-1} \cdot \mathrm{K}^{-1}\right)$. The critical temperature, $\mathrm{T}_{\mathrm{c}}$, of the ILs wasestimated using the Eo"tvo"s equation (1976, 3rd ed):

$$
\gamma \mathrm{V} 2 / 3=\mathrm{k}(\mathrm{Tc}-\mathrm{T})
$$

where $\mathrm{V}$ is the molar volume of the $\mathrm{IL}, \mathrm{Tc}$ is the critical temperature, and $\mathrm{k}$ is an empirical constant. The linear regression of the product of $\gamma$ and $\mathrm{V}^{2 / 3}$ for $\left[\mathrm{C}_{2} \mathrm{mim}\right][\mathrm{SCN}]$ against absolute temperature $\mathrm{T}$ was made. A good straight line was obtained, $\gamma \mathrm{V}^{2 / 3}=1.87 \cdot 10^{-4}-1.4 \cdot 10^{-7} \mathrm{~T}$, and the correlation coefficient is 0.91 . From the slope of the straight line, the values of $\mathrm{k}=1.4 \cdot 10^{-7} \mathrm{~J} \cdot \mathrm{K}^{-1}$ and from the intercept $\mathrm{Tc}=1331 \mathrm{~K}$ were obtained, respectively. For the majority of organic liquids $\mathrm{k}$ is near $2.1 \times 10^{-7} \mathrm{~J} / \mathrm{K}$, but with respect to fused salts polarity $\mathrm{k}$ is rather small, for example, $\mathrm{k}=0.4 \times 10^{-7} \mathrm{~J} / \mathrm{K}$ for fused $\mathrm{NaCl}$. This implies that $\left[\mathrm{C}_{2} \mathrm{mim}\right][\mathrm{SCN}]$ has polarity betewen organic liquid and fused salt, and therefore, the magnitude of $\mathrm{k}$ may be taken to represent the polarity of ionic liquid.

According to Rebelo, $\mathrm{Tb}$ of $\left[\mathrm{C}_{2} \mathrm{mim}\right][\mathrm{SCN}]$ is approximately $799 \mathrm{~K}$. Using the aforementioned normal boiling point of $\left[\mathrm{C}_{2} \mathrm{mim}\right][\mathrm{SCN}]$ and a Trouton's constant $\left(\approx 90 \mathrm{~J} \cdot \mathrm{mol}^{-1} \cdot \mathrm{K}^{-1}\right)$, the molar enthalpy of vaporization at TNBP for this ionic liquid was estimated to be $71.9 \mathrm{~kJ} \cdot \mathrm{mol}^{-1}$. The difference between $\Delta_{l}^{g} H_{m}^{0}\left(\mathrm{~T}_{\mathrm{b}}\right)$ estimated by Rebelo's method and $\Delta_{l}^{g} H_{m}^{0}(298 \mathrm{~K})$ estimated by Kabo's method is caused by the heat capacity difference between the liquid and the gas phases at different temperatures. Supposing linear change of $\Delta_{l}^{g} H_{m}^{0}$ with temperature in the temperature range between $298 \mathrm{~K}$ and $\mathrm{Tb}$, the vapour pressure, $\mathrm{p}$, of the IL may be estimated by the Clapeyron-Clausius equation. The values of $\mathrm{p}$ are $101.325 \mathrm{kPa}$ at $799 \mathrm{~K}$. The estimated value of $\mathrm{p}$ at $\mathrm{T}=$ $298 \mathrm{~K}$ was $3.9 \cdot 10^{-17} \mathrm{KPa}$ for $\left[\mathrm{C}_{2} \mathrm{mim}\right][\mathrm{SCN}]$. The value of $\mathrm{p}$ at $\mathrm{T}=298 \mathrm{~K}$ is very small and the result is in good agreement with our experience: ionic liquids have a negligible vapour pressure at ambient temperature. The hypothetical vapor pressures, $\mathrm{p}$, of $\left[\mathrm{C}_{2} \mathrm{mim}\right][\mathrm{SCN}]$ at different temperatures may be estimated by eq 7 (that is, the Clapeyron-Clausius equation). The calculated values of $\Delta_{l}^{g} H_{m}^{0}$ and $\mathrm{p}$ at various temperatures are listed in Table 3. Figure 3 is the plot of vapor pressure, $\mathrm{p}$, and $\Delta_{l}^{g} H_{m}^{0}$ of $\left[\mathrm{C}_{2} \mathrm{mim}\right][\mathrm{SCN}]$ against temperature, $\mathrm{T}$.

$$
\ln (\mathrm{p} 2 / \mathrm{p} 1)=\left(\Delta_{l}^{g} H_{m}^{0} / \mathrm{R}\right)\left(1 / \mathrm{T}_{1}-1 / \mathrm{T}_{2}\right)
$$

\subsection{Interstice Model for Ionic Liquid}

For a pure ionic liquid, a new theoretic model of Yang, J. Z. (2006, 110, 22521-22524) has been put forward on the basis of the following assumptions: (1) Because of the large size and the asymmetric shape, the ions may not be closely packed, and lots of interstices between ions exist. (2) To calculate the volume, the interstice is regarded as a bubble. (3) There are $2 \mathrm{~N}$ interstices for $1 \mathrm{~mol}$ of 1:1 ionic liquid, where $\mathrm{N}$ is Avogadro's constant. (4) The interstice in $\left[\mathrm{C}_{2} \mathrm{mim}\right][\mathrm{SCN}]$ can move about like an ion or another particle, and in the movement, the interstice does not vanish but can be compressed and expanded, which has an extra feature of motion of an interstice called the breathing motion. According to the same procedure of the whole model of molten salt, the expression of calculation of interstice volume, $v$, was obtained on the classical statistical mechanics

$$
\mathrm{N}=0.6791(\mathrm{kbT} / \gamma) 3 / 2
$$


where $\mathrm{k}_{\mathrm{b}}$ is the Boltzmann constant; $\mathrm{T}$ is thermodynamic temperature; and $\gamma$ is surface tension of the ionic liquid. According to eq 8 , the values of the average volume of the interstices of ionic liquids at different temperatures are obtained. From Table 1, the surface tension of $\left[\mathrm{C}_{2} \mathrm{mim}\right][\mathrm{SCN}], \gamma$, is $57.8 \cdot 10^{-3} \mathrm{~J} \cdot \mathrm{m}^{-2}$, at $298.15 \mathrm{~K}$, and the average volume of the interstice, $v$, is $12.90 \cdot 10^{-24} \mathrm{~cm}^{3}$. Then, the total volume of the interstice is $\Sigma v=2 \mathrm{Nv}=$ $15.53 \mathrm{~cm}^{3}$. The volume fraction of interstice, $\Sigma v / V$, is about $12 \%$ for ionic liquid $\left[\mathrm{C}_{2} \operatorname{mim}\right][\mathrm{SCN}]$. This value most closely approaches those of the majority of materials which exhibit (10 to 15$) \%$ volume expansion in the process from the solid to the liquid state. The volume of ionic liquid, $\mathrm{V}$, consists of the inherent volume, $\mathrm{Vi}$, and the total volume of the all interstices, $\Sigma v=2 \mathrm{Nv}$; that is

$$
\mathrm{V}=\mathrm{Vi}+2 \mathrm{Nv}
$$

If the expansion of IL volume only results from the expansion of the interstices when temperature increases, then calculation expression of $\alpha$ was derived from the interstice model

$$
\mathrm{A}=(1 / \mathrm{V})(\partial \gamma / \partial T) \mathrm{p}=3 \mathrm{Nv} / \mathrm{VT}
$$

The value of $\alpha$ (calculated) $=6.2 \cdot 10^{-4} \mathrm{~K}^{-1}$ at $298.15 \mathrm{~K}$, and that of $\alpha$ (experimental) $=5.46 \cdot 10^{-4} \mathrm{~K}^{-1}$; that is, $\alpha$ (calculated) was compared with the experimental one.

\subsection{Surface Tension of [Cnmim][SCN] Predicted by Parachor}

Though the parachor, $P$, is a relatively old concept that relates the surface tension $(\gamma)$ and density $(\rho)$ of a substance using eq 11 , Deetlefs, et al. $(2006,8,642-649)$ pointed out that it is a remarkably useful tool to predict physicochemical properties of ILs.

$$
\mathrm{P}(298.15 \mathrm{~K})=(\mathrm{M} \gamma 1 / 4) / \rho
$$

where $\mathrm{M}$ is molar mass and. According to equation (11), the experimental values of the parachor of $\left[\mathrm{C}_{2} \mathrm{mim}\right][\mathrm{SCN}], \mathrm{P}=348.5$ at $\mathrm{T}=298.15 \mathrm{~K}$, was obtained.Considering the methylene $\left(-\mathrm{CH}_{2}-\right)$ group in the alkyl chains of the imidazolum-based ionic liquids has almost the same chemical environment, Tong' group (2008, 112, 4381-4386) have put forward the semiempirical method of predicting P of the ILs that is an experimental value of parachor for a compound of the homologue of ILs plus the contributions of per methylene $\left(-\mathrm{CH}_{2}-\right)$ to parachor.

$$
\mathrm{P}\left(\left[\mathrm{C}_{\mathrm{n}+1} \mathrm{mim}\right][\mathrm{SCN}]\right)=\mathrm{P}\left(\left[\mathrm{C}_{\mathrm{n}} \mathrm{mim}\right][\mathrm{SCN}]\right)+\mathrm{P}\left(-\mathrm{CH}_{2}-\right)
$$

the contributions of per methylene $\left(-\mathrm{CH}_{2}-\right)$ to parachor are 31.1 from the homologous series of ILs $\left[\mathrm{C}_{\mathrm{n}} \operatorname{mim}\right]\left[\mathrm{AlCl}_{4}\right], 31.0$ from $\left[\mathrm{C}_{\mathrm{n}} \mathrm{mim}\right]\left[\mathrm{GaCl}_{4}\right]$ reported by Tong $(2007,111,3197-3120)$, and 30.9 from $\left[\mathrm{C}_{\mathrm{n}} \mathrm{mim}\right]\left[\mathrm{InCl}_{4}\right]$ reported by Tong $(2007,52(4), 1497-1500)$, so that the average is 31.0. For this reason, the values of parachor for the homologue of $\left[\mathrm{C}_{\mathrm{n}} \mathrm{mim}\right]$ can be predicted. Since the parachor is available as a link between the structure, density, and surface tension, it may become a tool to predict the properties of ILs. Therefore, and the predicted values of surface tension using equation (12) for the homologue $\left[\mathrm{C}_{n} \operatorname{mim}\right][\mathrm{SCN}](\mathrm{n}$ $=3,4$ ) are listed in table 4 . Based on the information in table4, lengthening the chain size of the alkyl substituent of the cation results in lowering the surface tension.

Comparing the predicted and experimental thermal expansion coefficients at $298.15 \mathrm{~K}$, the estimation and prediction values of interstice fractions, $\Sigma v / V$, are in the range of (6 to 21$) \%$ for all ILs $\left[\mathrm{C}_{\mathrm{n}} \operatorname{mim}\right][\mathrm{SCN}](\mathrm{n}=2,3$, 4,) at $298.15 \mathrm{~K}$; these values are in good agreement with the values of volume expansion resulting in the process from a solid to a liquid state for the majority of materials which exhibit (10 to 15) \%. This means that the interstice model is reasonable, and the interstice model theory can be applied to calculate the thermal expansion coefficient of imidazolium-based ILs.

\section{Conclusions}

The density and surface tension of the IL $\left[\mathrm{C}_{2} \mathrm{mim}\right][\mathrm{SCN}]$ were determined in the temperature range of (298.15 to $338.15) \mathrm{K}$. The surface entropy of the IL, Sa $=76 \cdot 10^{-3} \mathrm{~mJ} \cdot \mathrm{K}^{-1} \cdot \mathrm{m}^{-2}$, were estimated by extrapolation, respectively. In terms of Glasser's theory, the standard molar entropy, $\mathrm{S}^{0}(298 \mathrm{~K})=291.1 \mathrm{~J} \cdot \mathrm{K} \cdot \mathrm{mol}^{-1}$, and lattice energy, UPOT $=498.6 \mathrm{~kJ} \cdot \mathrm{mol}^{-1}$, of the IL were estimated, respectively. Using Kabo's method and Rebelo's method, the molar enthalpy of vaporization of the IL, $\Delta_{l}^{g} H_{m}^{0}(298 \mathrm{~K})=140.2 \mathrm{~kJ} \cdot \mathrm{mol}-1$, and $\Delta_{l}^{g} H_{m}^{0}\left(\mathrm{~T}_{\mathrm{b}}\right)=71.9 \mathrm{~kJ} \cdot \mathrm{mol}^{-1}$, at a hypothetical normal boiling point, $\mathrm{Tb}=799 \mathrm{~K}(\mathrm{~Tb} \approx 0.6 \mathrm{Tc})$ were estimated, respectively. According to the interstice model, the thermal expansion coefficient $\alpha$ (cal.) $=6.2 \cdot 10^{-4} \mathrm{~K}^{-1}$ at $298.15 \mathrm{~K}$, which was in good agreement with experimental $\alpha(\exp )=.5.46 \cdot 10^{-4} \mathrm{~K}^{-1}$ of $\mathrm{IL}\left[\mathrm{C}_{2} \mathrm{mim}\right][\mathrm{SCN}]$. Since per methylene $\left(-\mathrm{CH}_{2}-\right)$ group in the alkyl chains of the imidazolium-based ionic liquids has almost the same chemical environment, using 
semiempirical methods we may predict physicochemical properties of 1-alkyl-3-methylimidazolium thiocyanate $\left[\mathrm{C}_{\mathrm{n}} \operatorname{mim}\right][\mathrm{SCN}](\mathrm{n}=3,4,5,6)$ : the molecular volume, $\mathrm{Vm}$, the standard molar entropy, $\mathrm{S}^{0}$, the parachor, $\mathrm{P}$, the surface tension, $\gamma$, and the molar enthalpy of vaporization, $\Delta_{\mathrm{g}}^{1} H_{\mathrm{m}}{ }^{0}$.

\section{References}

Adamson, A.W. (1976). Physical chemistry of surfaces. (3rd ed). John-Wiley: New York.

Deetlefs, M., Seddon, K. R., \& Shara, M. (2006). Phys. Chem. Chem. Phys., 8, 642-649. http://dx.doi.org/10.1039/b513453f

Fang, D. W., Guan, W., Tong, J., Wang, Z. W., \& Yang, J-Z. (2008). Study on Physicochemical Properties of Ionic Liquids Based on Alanine [Cnmim][Ala] $(\mathrm{n}=2,3,4,5,6)$. J. Phys. Chem. B, 112, 7499-7505. http://dx.doi.org/10.1021/jp801269u

Glasser, L. (2004). Lattice and phase transition thermodynamics of ionic liquids. Thermochim. Acta, 421, 87-93. http://dx.doi.org/10.1016/j.tca.2004.03.015

L. Alonso, A. Arce, M. Francisco, \& A. Soto. (2008). Fluid Phase Equilib, 270, 97-102. http://dx.doi.org/10.1016/j.fluid.2008.06.012

Rebelo, L. P. N., Canongia, J. N., Esperanca, J. M. S. S., \& Filipe, E. (2005). On the Critical Temperature, Normal Boiling Point, and Vapor Pressure of Ionic Liquids. J. Phys. Chem. B, 109, 6040-6043. http://dx.doi.org/10.1021/jp050430h

Tong, J., Liu, Q. S., Xu, W. G., Fang, D. W., \& Yang, J-Z. (2008). Estimation of Physicochemical Properties of Ionic Liquids 1-Alkyl-3-methylimidazolium Chloroaluminate. $J$. Phys. Chem. B, 112, 4381-4386. http://dx.doi.org/10.1021/jp711767z

Tong, J., Liu, Q.-S., Guan, W., \& Yang, J-Z. (2007). Estimation of Physicochemical Properties of Ionic Liquid C6MIGaCl4 Using Surface Tension and Density. J. Phys. Chem. B, 111, 3197-3120. http://dx.doi.org/10.1021/jp068793k

Tong, J., Liu, Q-S, Zhang, P., \& Yang, J-Z. (2007). The surface tension and density of 1-methyl-3-hexylimidazolium chloroindium. J. Chem. Eng. Data, 52(4), 1497-1500. http://dx.doi.org/10.1021/je700102g

U. Doman' ska, A. Pobudkowska, \& M. Krolikowski. (2007). Fluid Phase Equilib, 259, 173-179.

Yang, J. Z., Zhang, Q. G., Wang, B., \& Tong, J. (2006). Study on the properties of amino acid ionic liquid EMIGly. J. Phys. Chem. B, 110, 22521-22524. http://dx.doi.org/10.1021/jp0648691

Zaitsau, D. H., Kabo, G. J., Strechan, A. A., Paulechka, Y. U., Tschersich, A., Verevkin, S. P., \& Heintz, A. (2006). Experimental VaporPressures of 1-Alkyl-3-methylimidazolium Bis(trifluoromethylsulfonyl) imides and a Correlation Scheme for Estimation of Vaporization Enthalpies of Ionic Liquids. J. Phys. Chem. A, 110, 7303-7306. http://dx.doi.org/10.1021/jp060896f

Table 1. The values of density and Surface Tension of Ionic Liquid at $298.15-338.15 \mathrm{~K}$

\begin{tabular}{cccccc}
\hline $\mathrm{T} / \mathrm{K}$ & 298.15 & 308.15 & 318.15 & 328.15 & 338.15 \\
\hline$\rho / \mathrm{kg} \cdot \mathrm{m}^{-3}$ & 1.11682 & 1.11063 & 1.10478 & 1.09874 & 1.09260 \\
$\gamma / \mathrm{mJ} \cdot \mathrm{m}^{-2}$ & 57.8 & 57.0 & 56.2 & 55.4 & 54.8 \\
\hline
\end{tabular}

Table 2. Predicted Volumetric Properties of the Homologous Series [Cnmim][ SCN] $(\mathrm{n}=2,3,4,5,6)$ at 298.15 $\mathrm{K}$

\begin{tabular}{cccccc}
\hline Ionic Liquid & $\rho / \mathrm{kg} \cdot \mathrm{m}^{-3}$ & $\mathrm{Vm} / \mathrm{nm}^{3}$ & $\mathrm{~S}_{0} /{\mathrm{J} \cdot \mathrm{K}^{-1} \mathrm{~mol}^{-1}}^{\mathrm{V} / \mathrm{cm}^{3} \cdot \mathrm{mol}^{-1}}$ & $\mathrm{Upot} / \mathrm{kJ} \cdot \mathrm{mol}^{-1}$ \\
\hline$\left[\mathrm{C}_{2} \mathrm{mim}\right][\mathrm{SCN}]$ & $\mathrm{a} 1.11682$ & $\mathrm{a} 0.2099$ & $\mathrm{a} 291.1$ & $\mathrm{a} 126.4$ & $\mathrm{a} 498.6$ \\
{$\left[\mathrm{C}_{3} \mathrm{mim}\right][\mathrm{SCN}]$} & 0.98744 & 0.2374 & 325.4 & 142.9 & 482.7 \\
{$\left[\mathrm{C}_{4} \mathrm{mim}\right][\mathrm{SCN}]$} & 0.88492 & 0.2649 & 359.7 & 159.5 & 469.1 \\
{$\left[\mathrm{C}_{5} \mathrm{mim}\right][\mathrm{SCN}]$} & 0.80168 & 0.2924 & 393.9 & 176.1 & 457.3 \\
{$\left[\mathrm{C}_{6} \mathrm{mim}\right][\mathrm{SCN}]$} & 0.73276 & 0.3199 & 428.2 & 192.6 & 446.8 \\
\hline
\end{tabular}

a Experimental value. 
Table 3. Predicted Values of $\Delta_{l}^{g} H_{m}^{0}$ and $\mathrm{p}$ of $\left[\mathrm{C}_{2} \operatorname{mim}\right][\mathrm{SCN}]$ at Various Temperatures

\begin{tabular}{ccccccc}
\hline$T / K$ & 799 & 700 & 600 & 500 & 400 & 298 \\
\hline$\triangle_{l}^{g} H_{m}^{0} /{\mathrm{KJ} \cdot m o l^{-1}}^{2}$ & 71.9 & 84.5 & 98.2 & 111.8 & 125.5 & 140.2 \\
$P / P a$ & $0.1 \cdot 10^{6}$ & 0.016 & $7.5 \cdot 10^{-4}$ & $4.2 \cdot 10^{-6}$ & $6.6 \cdot 10^{-10}$ & $3.9 \cdot 10^{-17}$ \\
\hline
\end{tabular}

Table 4. Estimated and Predicted Values of Physicochemical Properties of $\operatorname{IL}\left[\mathrm{C}_{n} \operatorname{mim}\right][\mathrm{SCN}](\mathrm{n}=3,4)$ at 298.15 $\mathrm{K}$

\begin{tabular}{|c|c|c|c|}
\hline properties & $\left.\left[\mathrm{C}_{2} \mathrm{mim}\right] \mathrm{SCN}\right]^{\mathrm{b}}$ & $\left.\left[\mathrm{C}_{3} \mathrm{mim}\right] \mathrm{SCN}\right]^{a}$ & $\left.\left[\mathrm{C}_{4} \mathrm{mim}\right] \mathrm{SCN}\right]^{a}$ \\
\hline $\mathrm{M} / \mathrm{g} \cdot \mathrm{mol}^{-1}$ & 141.15 & 155.16 & 169.17 \\
\hline$P$ & 348.5 & 379.5 & 410.5 \\
\hline$\gamma / \mathrm{mJ} \cdot \mathrm{m}^{-2}$ & $57.8^{c}$ & 34.1 & 21.3 \\
\hline $10^{24} \mathrm{v} / \mathrm{cm}^{3}$ & 12.9 & 28.6 & 57.8 \\
\hline$\Sigma v / \mathrm{cm}^{3}$ & 15.53 & 34.4 & 69.4 \\
\hline $10^{2} \Sigma v / V$ & 12 & 24 & 43 \\
\hline $10^{4} \alpha / K^{-1}$ & $5.46^{c}$ & & \\
\hline $10^{4} \alpha / K^{-1}$ & 6.2 & 12.1 & 21 \\
\hline$\Delta_{l}^{g} H_{m}^{0} / K J \cdot m o l^{-1}$ & 140.2 & 90.6 & 61.7 \\
\hline
\end{tabular}

a Data in the column were predicted values. b Data in the column were estimated values. c Experimental data. 